\title{
EVALUATION OF THE CHRISTIAN RELIGIOUS EDUCATION LEARNING PROGRAM USING THE CSE-UCLA EVALUATION MODEL AT THE PPD SOCIAL WELFARE INSTITUTION IN KOTA BATU
}

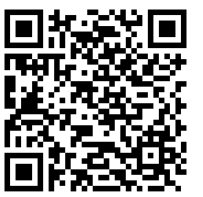

\author{
Djoys Anneke Rantung ${ }^{* 1} \bowtie$, Susan Latupeirissa ${ }^{1}$ \\ ${ }^{* 1}$ Christian Religious Education Master Program, Postgraduate Program, Universitas Kristen \\ Indonesia
}

DOI: https://doi.org/10.29121/granthaalayah.v9.i3.2021.3812

Article Type: Research Article

Article Citation: Djoys Anneke Rantung, and Susan Latupeirissa. (2021). EVALUATION OF THE CHRISTIAN RELIGIOUS EDUCATION LEARNING PROGRAM USING THE CSE-UCLA EVALUATION MODEL AT THE PPD SOCIAL WELFARE INSTITUTION IN KOTA BATU. International Journal of Research GRANTHAALAYAH, 9(3), 278-287. https://doi.org/10.29121/granthaa layah.v9.i3.2021.3812

Received Date: 16 March 2021

Accepted Date: 31 March 2021

Keywords:

Evaluation

CES-UCLA

Learning Program

PAK

\section{ABSTRACT}

A good lesson should involve an evaluation based on the results or outputs of the teaching-learning transformation process and pays attention to evaluating each program component in the learning process itself. Educators in the field are busily spurring students to obtain satisfactory evaluation results. It holds meaningful learning is equally important to evaluate whether the learning that educators do is good or still needs to be improved or even replaced. It is necessary to evaluate the learning program. The Doulos recovery cottage social welfare institution that has handled mental illness clients using PAK learning therapy needs to be evaluated. The PAK learning program's evaluation for psychic clients at the Doulos recovery cottage, Batu City, East Java social welfare-knowing the CSE-UCLA evaluation model for the PAK learning program using four stages of question variables. Every psychic client can be handled appropriately for a good recovery.

\section{INTRODUCTION}

Evaluation has often been heard, and not everyone realizes that we are doing evaluation work all the time. In some daily activities, we make assessments and measurements, which means there is evaluation in them. Also, in the evaluation world, education is not something strange or even necessary with the evaluation. It is hoped that education will be better [1], [2]. Because seeing the evaluation system to be very important for better education, in this discussion, the author will explain more about the evaluation process in a Christian religious education run by the zone of schools, churches, and other Christian institutions.

It should be noted that Christian religious education is a conscious effort to systematically educate students to experience and know Jesus Christ as the Lord and Savior of humankind and the Bible as the primary source of learning, which leads them to have a correct knowledge of God, full maturity, firm faith in the world. Christian Religious Education (after this will be abbreviated as $P A K$ ) is theological because all aspects of education come from

(C) 2021 The Author(s). This is an open access article distributed under the terms of the Creative Commons Attribution License, which permits unrestricted use, distribution, and reproduction in any medium, provided the original author and source are credited. 
the Bible [3]. The Word of God is a written source of teaching the Christian faith, revealed by the Holy Spirit and is the basis and primary source of Christian religious education material and educating students to grow and know Jesus Christ as Savior is the main task of educators to carry out the mandate that Jesus has given through formal and informal educational processes.

Christian religious education is theological because all aspects of education are biblical. God's Word is a written source of Christian faith learning, revealed by the Holy Spirit and is the basis and primary source of Christian religious education material. Christian religious education is present in the community to carry out the Lord Jesus Christ's great commission. Besides, the presence of $P A K$ can play a role in improving the quality of Indonesian people. $P A K$ must continue to develop in line with the progress of the times; enable people to be aware of science and technology, be creative, innovative, and have high solidarity; sensitive to the context of national education, national struggles and responding to the needs of believers [4],[5]. Therefore, $P A K$ learning cannot be separated by everyone who believes in Jesus Christ because $P A K$ is here, not only for knowledge but also for making every believer more familiar with Jesus Christ as Lord and Savior.

In a person, $P A K$ means that $P A K$ can affect a person's personality. They pay more or less attention to human personality formation (personal identity). The $P A K$ Learning Program is indispensable at every level of life because it is one of the essential things in human life, and $P A K$ teaching itself is God-centered with a biblical basis [6]. Therefore, when the PAK learning program is carried out, an essential concern is how the program concept, the process taught, and the results taught can be evaluated for progress and development to the next stage through more systematic teaching.

When a learning program, especially $P A K$, has been implemented, it is essential to evaluate. Evaluation comes from the word evaluation (in English). The Word is absorbed into Indonesian terms' vocabulary to preserve the original Word with a slight adjustment of the Indonesian pronunciation into evaluation. The term "valuation" is a noun of "value". The definition of "measurement" refers to the activity of comparing something with a particular unit of measure [7],[8]. This explanation means that evaluation is an activity to gather information about something done and be used as material for consideration and assessment to make better decisions and alternatives to work. In this case, the writer tries to do this evaluation system for an educational program that is already running, especially in the $P A K$ learning process, which is the main target of this ongoing learning. The author's primary reference here is to evaluate a learning program running for a long time for the informal education system in a Christian institution that runs the $P A K$ program [9].

In general, the implementation of $P A K$ is carried out in three areas, namely family, church and school $P A K$, church $P A K$ is called Church $P A K$, and school $P A K$ is called school $P A K$, and church $P A K$ is the church's duty and responsibility to administer to all members of the congregation. However, with the implementation of $P A K$ within the scope of Christian institutions or social welfare foundations that are directly involved in holistic services for the treatment of patients with mental or psychological disorders, it is essential to pay attention to where these clients also need treatment not only from psychologically but also from the side of faith in Jesus Christ [10]. In this case, educators, Christian coaches, and Christian clergy involved in healing services in social institutions or foundations must pay special attention to dealing with psychiatric disorders, not only with psychotherapy techniques but also with Christian religious education efforts for handling client recovery.

Here the author focuses on evaluating the $P A K$ learning program that takes place as a therapeutic activity for the recovery of Psychic clients in one of the institutions, namely the Doulos Recovery Center for Social Welfare Institutions (after this written as PPD) Kota Batu, East Java is currently running or has been running before. The problem of psychiatric disorders, which is called psychic, is also an important part that is handled explicitly by the PPD Social Welfare Institution in Batu City, East Java. In general, this PPD Social Welfare Institution runs a therapy called community therapy, where this therapy is a social rehabilitation method carried out jointly by a group of people for recovery for all clients [11]. In the ongoing therapy, the Christian religious education learning program is also part of the ongoing community therapy, and each client follows the $P A K$ learning process, which is a mandatory program for the holistic recovery process. Because not only mentally these clients are disturbed but also spiritually. Every therapy helps clients recover mentally and spiritually, psychiatric disorders experienced by clients certainly require good handling, and especially in the Christian religious education learning program, it must be realized and implemented according to the client's needs.

This psychological condition is a condition in which the sufferer has difficulty distinguishing between reality and imagination. Symptoms that appear in psychic sufferers are delusions or delusions and hallucinations. Psychic handling can be done by administering drugs and psychotherapy. If not treated appropriately and promptly, this 
Evaluation of The Christian Religious Education Learning Program Using the CSE-UCLA Evaluation Model at The PPD Social Welfare Institution in Kota Batu

condition can impact the patient's ability to live socially [12]. The recovery process for each client must be taken seriously because, of course, the client who comes with a disease or disorder like this is not only mentally disturbed but also from the side of faith in Jesus Christ, of course, it also makes the client not know and have strong faith in the Savior, who is Jesus Christ, so it is essential to deal with it. The existence of a PAK learning program is also beneficial. However, the program cannot run properly if it is not evaluated in detail for each activity to answer the client's therapeutic needs at LKS PPD Batu. It is a problem found in therapy activities carried out by LKS PPD that the PAK learning program indicated not evaluated in a structured manner.

Through the observation of the author's interview with several sources who deal directly with these psychic sufferers-namely mentors or coaches at the PPD Social Welfare Institution, it is true that the explanation above regarding the psychic clients they serve, in the explanation via telephone this educated client has problems. There are quite a lot of problems, what comes is not just one problem, but several problems that make them mentally disturbed so that they are classified as psychic clients and come to recover. In the author's interview with this resource, it was also explained that every client has a problem in moral matters, but the disturbance they experience makes them do not know God and do not understand how their life of faith is in Jesus Christ [13]. Therefore, PAK is run as a form of therapy that can restore clients, and what is highlighted here is the evaluation process for the learning program that is already underway. The author indicates that the Institution does not use a specific evaluation model to determine the success of a program running specifically for $P A K$ learning program.

The problems in institutions, especially in the ongoing learning program for $P A K$, are still inadequate to recovery for psychological clients because the ongoing therapy program has to be updated a lot. Therefore, the process of evaluating the $P A K$ learning program that is already running must be appropriately used. The evaluation process becomes a reference for programs that can be assessed for good and bad, weaknesses and strengths to determine its success. The evaluation takes place every two weeks from the informants' information, but the evaluation is more general for all the client runs. In particular, the $P A K$ learning program itself does not exist, so the author sees this as a severe problem that the special evaluation for the $P A K$ learning process that is running does not have a wellaccepted measure of $P A K$ success as routine client activities at the Institution.

Because the Christian religious education learning program used in the therapy process is also one of the Institute's strategies, this program's evaluation must be carried out with a specific evaluation model [14]. As explained, clients who have psychiatric or psychic disorders need recovery, not only mentally but also spiritually, in knowing Jesus Christ, so PAK learning evaluation must also be necessary so that every teacher can find out the extent to which the level of success of the learning process is being carried out.

Based on the problem of handling psychological clients, the authors see that evaluation is essential and an evaluation model that can be used for institutions, namely the CSE-UCLA evaluation model. CSE-UCLA consists of two abbreviations, namely CSE and UCLA. CSE stands for Center for evaluation, while UCLA stands for the University of California in Los Angeles. The characteristic of the CSE-UCLA model is that there are four stages in the evaluation. They are namely planning, development, implementation, and results or impacts [15],[16]. From this evaluation model, the people in charge of institutions that specifically serve psychic clients will systematically evaluate each learning program with the correct planning, the best development, and implementation. It helps clients recover quickly, the results that are certainly seen from the recovery level, and the positive impact that the PAK learning program is significant to run. Of course, all these processes must be carried out according to a structured evaluation model. From the background of the problems described above, the authors are interested in researching the title "Evaluation of Christian Religious Education Learning Programs with the CSE-UCLA Evaluation Model in the Social Welfare Institution of $P P D$ Kota Batu, East Java". The problems answered in this study are: a) How to evaluate the $P A K$ learning program in handling the needs of psychological clients? b) How to find out the CSE-UCLA evaluation model for the $P A K$ learning program for psychic clients at the PPD Social Welfare Institution? and c) How can every psychic client/patient get proper treatment for their recovery at the PPD Social Welfare Institution?

\section{METHOD}

This study used a qualitative evaluative approach with data sources using the $P P D$ Kota Batu, East Java Social Welfare Institution, specifically for handling psychotic clients. The data obtained includes observations, interviews, 
documentation results, document analysis not written in numbers but expressed in words and pictures. The data collection techniques are through interviews, observation and documentation. The CSE-UCLA evaluation model was used to sort the collected data by category of planning, development, implementation, results and impact [15],[16]. This research was conducted by the Doulos Batu City Social Welfare Foundation's spiritual coaches or mentors, and this research was conducted for one month (May 2020), starting from initial data collection to complete data collection. The research informants are mentors/spiritual coaches who specifically handle psychotic patients/clients at the $P P D$ Kota Batu Social Welfare Foundation. The number of mentors who handle psychotic patients/clients at the PPD Kota Batu Social Welfare Foundation is four people consisting of 2 women and two men. Data analysis was performed using Miles and Huberman's techniques: data reduction, data display (data presentation), and consumption/verification (concluding/verification).

\section{RESULT AND DISCUSSION}

Evaluation of Learning Programs using the CSE-UCLA Model - To get information about what needs are needed in carrying out the $P A K$ learning program in $P P D$, researchers conducted interviews with the heads and mentors who deal specifically with psychological clients in the $P A K$ learning carried out. Focused on five questions related to need assessment:

The implementing the $P A K$ learning program, the things needed for the $P A K$ program's sustainability. From the informants' answers, the researchers got different answers. AT and MS said that with the implementation of the $P A K$ program, a lot was needed. We used teaching materials, Bibles, textbooks, teaching aids, and unique guidebooks. Furthermore, the mentor's sensitivity to motivate and teach creatively. Furthermore, the researcher got a different answer from what the informants said. According to MO, FL, the PAK learning program requires sufficient human resources and thorough readiness to teach clients with psychic or psychiatric disorders and must have the patience to serve well.

To get the results of the questions the researcher made, the researchers conducted interviews with several informants who had the same answers they said. According to AT, MS, FL, and MO said that the activities that have been running for the $P A K$ learning program are not as formal as the $P A K$ in school or church activities because there is a place for therapy with Christian guidance, so the $P A K$ activities we carry out for clients are classes. In class, we provide various materials with the given theme, and there is also morning piston, teaching and learning in class, memorizing verses of God's Word, guided study to review what was learned in class, and morning worship in which they listen to sermons and hymns to review in. class.

The researcher conducts interviews with informants to determine the answers to the questions the researcher gives. The four informants gave almost the same answers, and the following are the results of the interview. According to AT, MS, FL, and MO, clients become focused, pray, reduce client boredom, forget about the past, increase client knowledge and deepen God's Word. Get closer and grow the client's faith in the Lord Jesus. AT explained it was just that because the clients served were mentally ill people so that the success of each learning, they received took a long time, MO explained that it took a long time, but the mentors tried to help them so that they could receive the $P A K$ learning process well for their recovery.

The accuracy of the PAK learning program - According to AT, MS, FL, and MO, the informants gave answers that were essentially the same, that the $P A K$ Learning Program was right for the client because it was part of therapy for the client himself. There just has to be a lot to update about the mentor's materials, methods, and creativity.

Long-term goals achieved through the $P A K$ learning program. From the questions, the researcher gave the informants to provide answers, along with the answers. According to AT, every client who used to live recklessly can become more regular, respect their parents, know the time for church services, understand the purpose of delivering God's Word. With PAK's existence, they better understand that they (clients) are God's creation, which means valuable. Furthermore, MS explained that previously mentally disturbed could recover from being pessimistic about their existence, and they understood that they are valuable in God's eyes. Psychic client development becomes better recovered. Then FL said his long-term goal was that the client's lifestyle became orderly, and when they returned to their respective places, they could become servants of God. Dan MO explained that the long-term goal is to prepare clients to know God and when they return to their families and communities, they can be accepted and bless others.

From the questions the researchers asked, the informants had answers that were essentially the same: according to the AT formation class, the class grew in faith: inner healing wounds, restoring sexual abuse, self- 
Evaluation of The Christian Religious Education Learning Program Using the CSE-UCLA Evaluation Model at The PPD Social Welfare Institution in Kota Batu

esteem, fractured relationships, spiritual abuse. There is a textbook used as a guide; there is an SP in it. They will be given verses of God's words to memorize and be reviewed when in class and learn to understand the Bible. Furthermore, MS explained that personal counselling and group counselling are group prayers that have become routine activities. According to FL, the activities running so far specifically for the PAK learning program are classes about the Word of God. MO explained that the activities that run according to the PAK program had been planned in a particular schedule, which has become part of the PAK learning program, starting from waking up in the morning to their bedtime. Among them are morning devotions, morning worship, PAK learning classes, and guided study activities to discuss the Word of God again. Activities and activities that take place within the Institution, especially the $P A K$ learning program for psychic clients, have a good design, namely $P A K$ coaching and learning classes, and daily spiritual activities in them starting from meditation to daily life attitudes $P A K$ is very clear because they are part of the vision-mission of the agency.

From the questions, the researchers asked, the informants gave the following answers. According to MS, the method used is the sharing of life experienced in family and friends. The group grows together in which there are Bible study and mutual prayer. The method in the classroom when learning PAK will be given an assignment to be material for discussion together to understand God's Word. Furthermore, according to FL, the method in this PAK learning program is a dormitory, so it is not only sharing and studying the Word of God that they learn in class, but there is a part of the $P A K$, namely morning piston, as for worship together in which the Word of God they must pay attention to repeat in carefully then MO gives the answer that our method is a group and personal approach. In the class, there is a class discussion or question and answer.

The Institution, namely determine those who run the $P A K$ learning program: according to AT that those who run the $P A K$ learning program are specifically servants of God who are already in theological school and who are still in theological school but have entered the 5 th semester cannot be fixed, the point is good, if it is per cent, maybe 75\%. Furthermore, MS, MO and FL gave the same answer. Namely, those who run the PAK learning program for psychic clients are mentors who understand the teaching of God's Word well and who have attended theological school, including mentors who have the sensitivity to serve clients.

According to AT, MS, FL, and FO, they gave answers related to funding and the interview results. Sufficient funds have been prepared following the program to buy books, Bible, pens, and spiritual books. FL explained the source of funds was sufficient because it had been arranged directly from the Institution with the nominal expenditure detailed in a directed manner. The funds are well available. Regarding the funds, MS and FL answered that human resources or mentors were not enough and we are still very much needed because this client should be specially assisted. Furthermore, according to AT and MO, the mentor who handles PAK learning is enough.

According to AT that how well this program runs, the Institution carries out the $P A K$ learning program according to the stages of psychological client development in which there are three stages, namely stage (class) A: Question and answer, sharing, Stage B: using concrete examples, and Stage C using props and pictures. So, the level of learning ability is following the stage of the client's thinking power. Furthermore, MS explained that this program has been running well; it is just that sometimes clients are often annoyed by their bad feelings suddenly coming. So, there must be good handling and sensitivity to understand the client. Furthermore, this program has been running according to the regulated curriculum.

Furthermore, FL said that the PAK learning program for psychic clients had run quite well and everything is well organized according to the $P A K$ learning plan itself, although there are still many shortcomings that need to be continuously updated. MO explained that we could not accept it well if you see it well, so we used the stage from the beginning. If those who can connect can understand the learning process, but clients who find it difficult to accept, they must need high creativity to understand the learning theme.

The third variable is the Second focus: Place or atmosphere or comfort in PAK learning. AT and FL Explain, the conditions for the place to be comfortable are still not because all classes $\mathrm{A}$ to $\mathrm{C}$ are still combined, because the place is not yet a place, so the Institution is not yet conditioned to make the right place. Nevertheless, the priority is that there are still tables and chairs. Then MS and MO explained that the place's condition was comfortable because psychological clients needed a different place from formal classes such as in school. Although there is a class intermingling, it is still comfortably suitable for the client.

Barriers and supports from the PAK Learning program. AT, MS, FL, and MO explained if there are no obstacles, all support because spiritual programs are essential and primary because this is part of holistic recovery. 
Regarding the time and duration used for the PAK learning program. According to AT and MO, we conduct lessons, especially PAK learning for psychic clients, for one hour. It is divided into Class A for one hour, class B for 30 minutes, and class C for 15 minutes. Every Monday and Wednesday 11.30-12.30. Furthermore, MS and FL said that the $P A K$ learning program would last one hour every Monday and Wednesday. There is a piston in the morning and a group service held every day to continue to instil God's Word in each client's personality to support the PAK program.

Behaviour changes when the PAK learning program occurs for psychological clients. AT, FL, MO, and MS provide the core of the same answer: the behaviour or activity that changes from the client is that the client is more interested in the Bible, who previously did not know praying now can pray, previously unable to lead praise. Now can lead praise while playing music, who previously did not dare to testify about Jesus Christ, became courageous to testify who Jesus Christ was in their lives.

The benefits obtained from the PAK learning program; informants have the same core answers. According to AT that the benefits are not only for the client but also for the mentor. The mentor becomes honed and learns to understand everyone and has much special knowledge for psychiatric disorders. According to MS, clients and mentors feel more benefits when this learning program is running, clients can recover better, and mentors can be happy when they see clients recovering mentors. Furthermore, FL said that, of course, this PAK learning program is very beneficial for clients and also for mentors. Clients can recover physically and spiritually. It is also beneficial for the mentor because it allows the mentor to learn to provide proper $P A K$ learning. Then MO said that it was very beneficial for clients, particularly mentors and institutions in general because it was an assessment that the Institution carried out a good therapy process with the $P A K$ learning program.

The strengths and weaknesses of the existence of the PAK, AT, and FL programs explains that the weaknesses of the class or place are still inadequate and the influence of disease and the client's mindset which is sometimes difficult to control to receive $P A K$ learning. Clients' advantages can be guided, and the mentor also does not differentiate what kind of background the client is. The point here is that service with love is essential. Furthermore, MO explained, the advantage is that the client becomes close to God, for the mentor to be more loyal to serve psychiatric clients with patience, the advantage is also to reduce client boredom in dealing with their lives. The weakness is sometimes clients who are less stable due to their disturbances that come. Mentors are still less creative. Then MS answered that the weakness is sometimes no creativity makes the client bored, and the advantage is the intense application of God's Word that is instilled to make the client recover.

How well the client responds well to this program to meet client needs. AT, MS, MO, and FL provide answers with the same core that AT and MO say, this program has been running well enough to treat clients but not as perfect as $P A K$ learning in general. Furthermore, MS said that the PAK learning program was good, but there needed to be something new to design to create boredom in the ongoing learning program. According to FL, it is good because the Institution's motto is to humanize humans, so PAK is very helpful.

How efficient is the $P A K$ learning program? AT, FL and MS explained that the mentors who carried out this learning program were indeed active but not perfect and not $100 \%$ efficient, but it could be said that they were good. They only needed to continue to upgrade the mentors' abilities. Then MO explained that the PAK learning program was going there, in the sense that everything was imperfect, but so far, active mentors' dank lien was still able to follow, so it was efficient towards the better.

$P A K$ activities that contribute the most to the $P A K$ learning program, informants explain the same aims and objectives. According to AT, the most activities were counselling and second, morning, and third classes. Furthermore, MS explained the activities that contributed the most to the ongoing counselling and classes. According to FL, he explained that all $P A K$ learning programs' activities contributed significantly because they all depended on assistance and acceptance from clients. MO explained that for the PAK learning program itself, the class contributed very well because, in the classroom, the client could do question and answer and share and even do group prayers, namely pray for each other and good group work.

The indirect effect that comes positively or negatively is related to the $P A K$ learning program's existence. According to AT, MS, MO, and FL, it was explained that, for the negative influence, it might be psychologically for them, because sometimes when they feel that something makes them sad or gloomy, it will be disconcerting during learning in class and outside the classroom. Positively, of course, there are parties like their families who are very supportive so that they too can recover quickly. Furthermore, according to FL, everything is still going well so far and can still be controlled. MS, if the indirect influence of $P A K$ learning activities on psychological clients is negative, some families have too high demands for clients, so that it makes them quite depressed, and it is the responsibility 
Evaluation of The Christian Religious Education Learning Program Using the CSE-UCLA Evaluation Model at The PPD Social Welfare Institution in Kota Batu

of our mentors to assist them. On a positive note, some families already understand what kind of client they are to provide good support for their recovery. MO explained that the indirect effect might be a family intervention that demands too high a client's recovery. Of course, the positive thing is there are many fields of support, even from the local city government who also supports the therapy process in which there is religious learning in recovery institutions like this.

What can be learned with the $P A K$ learning program in the $P P D$ Institute for clients with mental disorders, namely: FL, AT, MO, and MS answered with the same core answer. According to AT, when other people know that $P P D$ is present to humanize humans through therapy, especially $P A K$ learning. Furthermore, MS explained, people out there can imitate that people who are psychologically ill will find it difficult, but if served with love, people with mental disorders will recover well and make people out there open their eyes that people with mental disorders it is worthy of love, acceptance, and value and meaning before God. FL and MO explained that what other people can learn is that $P P D$ is here to change people's views that psychological clients can change and recover and be better. Some have even become servants of God.

The process and mechanism for evaluating the $P A K$ learning program. From interviews with informants, the researchers found the following answers. According to AT, MS, FL, and MO, the particular PAK learning program was evaluated and evaluated, which we did only for one year the $P A K$ learning program process took place. Furthermore, AT explained, we evaluate how the client develops in learning. Then MO explained that we evaluated how the client's faith growth was with the PAK learning program, then FL and MS explained that we evaluated only the client's spiritual development process.

In connection with the first problem about the needs of a program, at this stage, the evaluator focuses on determining the problem by evaluating the ongoing learning program. Based on program evaluation definition, which is defined as a unit or unit of activities, the realization or implementation of a policy with a continuous process also involves a group of people to make a good change [17]. With some questions raised in essence about what things need to be considered in connection with the program's existence. What needs are met in connection to this program's implementation, and what are the long-term achievable goals through this program? The informants said that the necessary infrastructure was already available from the interview results, and some informants said that a significant need was human resources or teaching staff for the $P A K$ learning program. The long-term goals that have been planned for the $P A K$ learning program have also been structured, although it is seen that these long-term goals are still very monotonous with routine activities that cause client burnout to emerge.

In conjunction with Norman E. Gronlund's learning to formulate the following notion of evaluation: Evaluation is a systematic process to determine or make decisions to what extent learning objectives have been achieved by students [18],[19]. From the interview that took place, it can be concluded here that the importance of a program evaluation for the long-term goals of the program for the Institution and also from the evaluation, it can be seen that changes in the target targets of the learning program to reduce the suffering of clients who experience mental illness, encourage clients to live more optimally during the therapy period. Until they return to the environment where they came from, and more importantly, the client's life becomes closer to God even though it is still seen that the client's mental disorder problems require a long process and time to receive learning.

In the second stage of the CSE model, the evaluator collects data directly related to learning and leads to meeting the needs identified in stage one. In this planning stage, the PBM program is carefully evaluated to determine whether the learning plan has been prepared based on the needs analysis results. The evaluation of this stage cannot be separated from the goals that have been formulated [20]. From the interview results, the researchers found that the $P A K$ learning program was carried out in the learning class, and through other support, activities were followed to be repeated while in the re-learning class, and that was not all in learning. $P A K$ is also taught psychic clients to be critical in discussing and conducting group prayer together. In the implementation of this PAK learning program, it is clear that those who carry it out must be people who have graduated from theology and education or have a good understanding of the Bible. Although human resources are still lacking in terms of human resources, the learning program's implementation has gone quite well.

Understand the term religious education accurately that describes the investigation in general for the dimensions of religious life and the search with humans for the transcendent basis of existence [21]. So, it is clear that the Institution also thought that every client it served could feel the restoration process from the Lord Jesus Christ, who healed their lives for the better and regardless of the mental illness they experienced. 
According to Agustin, Campbell, and Werner, Christian religious education aims to teach people to see God and live happily. It is even to make everyone aware of fearing God, grow as a child of God, and fulfil God's call in the Christian fellowship and fulfil the call to be a Disciple of Jesus. Teaching must also be Bible-based, Christ-centered and dependent on the power of the Holy Spirit. Therefore, what is carried out by the Institution for the PAK learning program is indeed appropriate for people with mental disorders so that each client can gain knowledge of the correct Bible and become a true disciple of Jesus according to the teachings of $P A K$ [22],[23]. Of course, the Institution still has to think about the right strategy and method in carrying out the PAK learning program to make clients feel bored and bored.

In this third stage, the evaluator focuses on the implementation of the program. Thus, evaluators are expected to be genuinely involved in the program because they have to collect data and various program development information. This program's development is quite good from the ongoing research because there are class stages that are formed even though they are still combined in the learning class. All learning activities have full support to continue the process, the timeliness of learning is good, even though the learning process is still found to make clients become saturation caused by the learning program that was designed not to include appropriate methods and creativity to stimulate the thinking power of clients.

The determination of the CSE-UCLA evaluation model is straightforward. It appears that the $P A K$ learning program in the Institution is a process program whose main activity is to change something that is still raw to be made into a good processor output [24],[25]. It is hoped that the impact and results of evaluating the PAK learning program will collect all data about the program's results and impacts. Through this summative evaluation, it is hoped that it will be possible to know whether the program's objectives have been achieved and if they have not been searched for which parts have not and what the is. From the researchers' findings above, it can be concluded that the $P A K$ learning program has not been appropriately evaluated for the development of learning that is more varied and not monotonous. Even though it has been facilitated with complete infrastructure and good handling, of course, the learning program must continue to be evaluated to find out what to plan for the psychological client.

From the interview results obtained an overview of the evaluation results using the CSE-UCLA model. Researchers make it in tabular form.

Table 1: CSE-UCLA Evaluation Results

\begin{tabular}{|c|c|}
\hline Evaluation & Evaluation Result \\
\hline \multicolumn{2}{|r|}{ Need Assessment } \\
\hline $\begin{array}{l}\text { Concerning things that need to } \\
\text { be considered, what must be } \\
\text { met, and the program's long- } \\
\text { term goals. }\end{array}$ & $\begin{array}{l}\text { The need for infrastructure has been met; it is just that human resources are } \\
\text { still needed for more specialized handling processes for psychological clients. } \\
\text { The long term of this } P A K \text { learning program is still monotonous. }\end{array}$ \\
\hline \multicolumn{2}{|r|}{ Planning Program } \\
\hline $\begin{array}{l}\text { It was collecting data that is } \\
\text { directly related to learning and } \\
\text { leads to meeting needs. }\end{array}$ & $\begin{array}{l}\text { The } P A K \text { learning program in LKS } P P D \text { for psychological clients is divided } \\
\text { into several planned activities according to the specified time, even though } \\
\text { the methods and designs of } P A K \text { learning used are still monotonous and are } \\
\text { not evaluated for good development upgrades. }\end{array}$ \\
\hline \multicolumn{2}{|r|}{ Formative Evaluation } \\
\hline $\begin{array}{l}\text { Focuses on program } \\
\text { implementation. }\end{array}$ & $\begin{array}{l}\text { The } P A K \text { learning program has been running well, but the problem here is } \\
\text { clients' inadequate comfort. }\end{array}$ \\
\hline \multicolumn{2}{|r|}{ Summative Evaluation } \\
\hline $\begin{array}{l}\text { Collecting data on program } \\
\text { outcomes and impacts. }\end{array}$ & $\begin{array}{l}\text { This learning program results show that clients are getting to know Jesus } \\
\text { Christ and dare to testify about Jesus Christ, only the problem is found from } \\
\text { the indirect influence itself, namely the family that demands too high, which } \\
\text { makes the client bored to take part in the learning process. And sometimes, } \\
\text { the client's problematic condition makes this } P A K \text { learning difficult for clients } \\
\text { to accept }\end{array}$ \\
\hline
\end{tabular}

4. CONCLUSION 
After conducting research using qualitative evaluation research, reduction and data analysis in this study, conclusions and suggestions are made. A good lesson should involve an evaluation that is concentrated on the results or outputs of the teaching-learning transformation process and pays attention to evaluating each program component in the teaching and learning process itself. Here the authors conclude:

An evaluation of the PAK learning program for psychic clients at the Doulos recovery lodge, Batu City, East Java: Based on the results of the study using the CSE-UCLA evaluation, the evaluation of the PAK learning program at LKS $P P D$ Kota Batu, East Java concluded: that the field of handling psychological clients in Doulos It is good to carry out therapeutic activities using $P A K$ learning programs and are planned according to sufficient resources and infrastructure to carry out $P A K$ learning programs, but there are still things that need to be developed and replaced regarding the strategies and methods used in implementing $P A K$ learning. Although the Institution still carries out many limitations and shortcomings, the $P A K$ learning program for mentally ill clients is essential to pay attention to.

Knowing the CSE-UCLA evaluation model for the PAK learning program using four-variable stages of questions: With four variable stages using 22 questions contained in the CSE-UCLA evaluation model, LKS PPD Kota Batu knows more about how the $P A K$ learning program is evaluated systematically and in detail. What is the need for a program, how is the program's implementation being carried out, what is the context or core that the program wants to achieve to reach the impact and results seen in the program? Furthermore, it seems clear that there are still unfulfilled needs, namely human resources, comfortable conditions for learning places, and difficulties in controlling clients whose illnesses recur. This evaluation model can be used as a guideline for how institutions evaluate ongoing programs. Ideally, an educator can evaluate a comprehensive learning program, be able to evaluate himself, discuss the results with peers or even with field leaders and then be able to make a formal report of the evaluation of the learning program he is doing by including accurate data. Because it is better that educators and learning program designers, they should get used to asking what other needs must be met, how the implementation of the learning program, and the proper context, so that the results obtained are also proper.

Every psychological client can be handled appropriately for a good recovery: With the ongoing program evaluation activities using CSE-UCLA. It is essential to find out how far the PAK learning program carried out in the Institution can be evaluated to answer each client's needs exactly how it should be or the right way in providing $P A K$ learning for psychic clients who experience mental illness. In the interview above, it can be seen that clients still experience boredom due to the learning system that they cannot accept perfectly and teaching that makes clients bored because the methods used need to be updated. Therefore, evaluation becomes input in designing learning programs that will be updated optimally so that the learning carried out will always be better than what has been previously carried out.

\section{SOURCES OF FUNDING}

This research received no specific grant from any funding agency in the public, commercial, or not-for-profit sectors.

\section{CONFLICT OF INTEREST}

The author have declared that no competing interests exist.

\section{ACKNOWLEDGMENT}

None.

\section{REFERENCES}

[1] Rantung, D. A. (2019). Christian Religious Education for Families According to Isaac's Family Parenting in the Old Testament. Jurnal Shanan, 3(2), 63-76.

[2] Arikunto, S., \& Jabar, C. S. A. (2004). Evaluation of educational programs practical theoretical guidelines for education practitioners. Jakarta: Bumi Aksara. 
[3] Spector, S. (2009). Evangelicals and Israel: The Story of American Christian Zionism. OUP USA.

[4] McCoy, D. L., \& Rodricks, D. J. (2015). Critical Race Theory in Higher Education: 20 Years of Theoretical and Research Innovations: ASHE Higher Education Report, Volume 41, Number 3. John Wiley \& Sons.

[5] Tefbana, A., \& Rantung, D. A. (2020). Christian Religious Education Perspective on Disaster Theology and The Role of The Church in Facing Pendemic COVID 19. JURNAL LUXNOS, 6(1), 72-88.

[6] Rodrigues, H. P., \& Harding, J. S. (2008). Introduction to the Study of Religion. Routledge.

[7] Brighenti, A. M. (2018). The social life of measures: conceptualizing measure-value environments. Theory, Culture \& Society, 35(1), 23-44.

[8] Schönsleben, P., Heller, D. S., \& Joshi, V. V. (2010). Integral logistics management: operations and supply chain management in comprehensive value-added networks. CRC Press.

[9] Peck, K., Bowen, K., Rimland, E., \& Oberdick, J. (2016). Badging as micro-credentialing in formal education and informal education. Digital badging in education: Trends, issues, and cases, 82-92.

[10] Symington, S. H., \& Symington, M. F. (2012). A Christian model of mindfulness: Using mindfulness principles to support psychological well-being, value-based behavior, and the Christian spiritual journey. Journal of Psychology and Christianity, 31(1), 71.

[11] Tyas, E. H., \& Naibaho, L. (2019, November). The urgency of entrepreneurship learning in the industrial age of 4.0. In Journal of Physics: Conference Series (Vol. 1387, No. 1, p. 012032). IOP Publishing.

[12] Ekberg, O., Hamdy, S., Woisard, V., Wuttge-Hannig, A., \& Ortega, P. (2002). Social and psychological burden of dysphagia: its impact on diagnosis and treatment. Dysphagia, 17(2), 139-146.

[13] Willard, D. (2014). Renovation of the Heart: Putting on the Character of Christ. Tyndale House.

[14] Walvoord, B. E., \& Anderson, V. J. (2011). Effective grading: A tool for learning and assessment in college. John Wiley \& Sons.

[15] Ardana, I. M., Ariawan, I. P. W., \& Divayana, D. G. H. (2017). Measuring the effectiveness of BLCS model (Bruner, Local Culture, Scaffolding) in mathematics teaching by using expert system-based CSE-UCLA. International Journal of Education and Management Engineering, 7(4), 1.

[16] Ratminingsih, N. M., Mahadewi, L. P. P., \& Divayana, D. G. H. (2018). ICT-Based Interactive Game in TEYL: Teachers' Perception, Students' Motivation, and Achievement. International Journal of Emerging Technologies in Learning, 13(9).

[17] Chang, M. C., Shaeffer, S., Al-Samarrai, S., Ragatz, A. B., De Ree, J., \& Stevenson, R. (2013). Teacher reform in Indonesia: The role of politics and evidence in policy making. The World Bank.

[18] Gronlund, N. E. (1998). Assessment of student achievement. Allyn \& Bacon Publishing, Longwood Division, 160 Gould Street, Needham Heights, MA 02194-2310; tele.

[19] Gronlund, N. E. (1993). How to make achievement tests and assessments. Allyn \& Bacon.

[20] Dooley, S., Won, S. H., Heyne, J., Farouk, T. I., Ju, Y., Dryer, F. L., ... \& Brezinsky, K. (2012). The experimental evaluation of a methodology for surrogate fuel formulation to emulate gas phase combustion kinetic phenomena. Combustion and Flame, 159(4), 1444-1466.

[21] Conroy, J. C., Lundie, D., Davis, R. A., Baumfield, V., Barnes, L. P., Gallagher, T., ... \& Wenell, K. J. (2013). Does religious education work? A multi-dimensional investigation. A\&C Black.

[22] Barth, K. (2005). The Knowledge of God and the Service of God According to the Teaching of the Reformation: Recalling the Scottish Confession of 1560 (Gifford Lectures 1937 \& 1938). Wipf and Stock Publishers.

[23] Ogden, G. (2019). Discipleship essentials: A guide to building your life in Christ. InterVarsity Press.

[24] Crisp, G. T. (2012). Integrative assessment: reframing assessment practice for current and future learning. Assessment \& Evaluation in Higher Education, 37(1), 33-43.

[25] DiBello, L. V., Roussos, L. A., \& Stout, W. (2006). 31a review of cognitively diagnostic assessment and a summary of psychometric models. Handbook of statistics, 26, 979-1030. 